American Journal of Applied Sciences 9 (2): 158-167, 2012

ISSN 1546-9239

(C) 2012 Science Publications

\title{
Enhanced Production of Extracellular Alkaline Lipase by an Improved Strain of Pseudomonas aeruginosa MTCC 10,055
}

\author{
Deepali Bisht, Santosh Kumar Yadav and Nandan Singh Darmwal \\ Department of Microbiology, Centre of Excellence, \\ Faculty of Science, Dr. Ram Manohar Lohia Avadh University, \\ Allahabad Road, Faizabad- 224001, Uttar Pradesh, India
}

\begin{abstract}
Problem statement: Lipases are industrially important enzymes having applications in numerous industries. For easy commercialization it is necessary to produce lipases at industrial level which could be achieved by strain improvement and medium formulation. Approach: In the present study strain improvement of Pseudomonas aeruginosa MTCC 10,055 was done by chemical mutagenesis using mutagen 4-nitroquinoline1-oxide for alkaline lipase production. Different fermentation parameters affecting lipase production were optimized using one-variable-at-a-time approach. Results: The selected mutant (M-05) exhibited 3.6-fold higher productivity over wild type. Maximum alkaline lipase was produced when culture was incubated at $35^{\circ} \mathrm{C}$ with initial medium $\mathrm{pH}$ 9.0 in $28 \mathrm{~h}$ with inoculum density $0.5 \%$ (v/v) $\left(\mathrm{Abs}_{610^{-}}-1.0\right)$. Supplementation of production medium with combination of castor oil and starch as carbon source and Triton-X-100 as surfactant significantly influenced the alkaline lipase production. The composition of fully optimized medium was determined to be $\left(\mathrm{g} \mathrm{L}^{-1}\right)$ : $\left(\mathrm{NH}_{4}\right)_{2} \mathrm{SO}_{4}, 1.0 ; \mathrm{KH}_{2} \mathrm{PO}_{4}, 0.6 ; \mathrm{MgSO}_{4}, 0.4$; yeast extract, 0.2; castor oil, 2.0; starch 20.0; gum arabic, 5.0; Triton-X-100, 1.0. An overall 14-fold enhanced production was achieved after complete medium optimization. Conclusion/Recommendations: The improved strain was capable to produce high titer of alkaline lipase at flask level, which can be examined at fermentor level to obtain sufficient enzyme yield to meet the world wide industrial demand.
\end{abstract}

Key words: Alkaline lipase, chemical mutagenesis, 4-nitroquinoline1-oxide, medium optimization, Pseudomonas aeruginosa, gum arabic, enzyme yield

\section{INTRODUCTION}

Lipases (triacylglycerol acylhydrolase, EC 3.1.1.3) belong to the family of hydrolases that break carboxylic ester bonds. The triglycerides of long-chain fatty acids are natural substrates of lipases, however, they also act on hydrophobic esters of primary and secondary alcohols (Houde et al., 2004). Because of versatile functions they can be widely applied in the food, detergent, pharmaceutical, leather, textile, cosmetic, organic chemistry and paper industries (Jaeger and Reetz, 1998; Jaeger and Eggert, 2002). Regio-specific and fatty acid specific microbial lipases could immensely be exploited for retailoring of vegetable oils. Tailored vegetable oils with nutritionally important structured triacylglycerols and modified physicochemical properties have great prospective in the future market (Gupta et al., 2003).

Contrary to many other enzymes, remarkable activity and stability of lipases in non-aqueous environments, facilitates the catalysis of several unnatural reactions such as esterification and transesterification (Ghaly et al., 2010). Because of these unique properties, lipases are most attractive enzymes for use in organic chemical processes. In addition they do not usually require cofactors and they can be produced in high yields from microorganisms, especially bacteria and fungi (Jaeger and Reetz, 1998; Jaeger and Eggert, 2002).

The escalating demand of lipases in various industries, in the last few decades, necessitated the extension in both qualitative improvement and quantitative enhancement. Quantitative enhancement could be done by strain improvement and medium optimization, as the quantities produced by wild strains are low (Bapiraju et al., 2004). Improvement of the commercial applicability of microbial strains has been practiced for centuries (Parekh et al., 2000). Industrial strain improvement plays a central role in the commercial development of microbial fermentation processes (Zhao et al., 2010). Meanwhile, strain

Corresponding Author: Nandan Singh Darmwal, Department of Microbiology, Centre of Excellence,

Dr. Ram Manohar Lohia Avadh University, Faizabad, Uttar Pradesh, India Tel: 05278-247350 
improvement of the enzyme producer offers the greatest opportunity for cost effective production without significant capital outlay (Stanbury et al., 1995). This is achieved when a selected strain can synthesize a higher proportion of the product using the minimal quantity of raw materials (Zhao et al., 2010).

The aim of the present study is to improve the alkaline lipase production by strain improvement through chemical mutagenesis and medium improvement.

\section{MATERIALS AND METHODS}

Microorganism: The wild-type strain of $P$. aeruginosa, isolated in our laboratory from oil contaminated soil was used as a parent strain for mutagenesis. It was identified and deposited at Indian Institute of Microbial Technology (IMTECH), Chandigarh, India and given an accession number MTCC 10,055.

Inoculum preparation: The culture was grown in medium containing $\left(\mathrm{g} \mathrm{L}^{-1}\right):\left(\mathrm{NH}_{4}\right)_{2} \mathrm{SO}_{4}, 1.0 ; \mathrm{KH}_{2} \mathrm{PO}_{4}$, $0.6 ; \mathrm{MgSO}_{4}, 0.2$; yeast extract, 0.1 ; olive oil, 20; $\mathrm{pH}$ 9.0. The flasks were incubated at $37^{\circ} \mathrm{C}$ with shaking at $120 \mathrm{rpm}$ for overnight.

Strain improvement by chemical mutagenesis: The chemical mutagenesis of $P$. aeruginosa MTCC 10,055 cells were carried by exposing with 4-nitroquinoline1oxide (4-NQO, Sigma-Aldrich Chemical Pvt. Ltd, USA) by a modified method of Punt et al. (1987). The overnight grown culture was harvested by centrifugation at $10,000 \times \mathrm{g}$ for $10 \mathrm{~min}$, washed twice with phosphate buffer (100 mM, pH 7.2) and suspended in the same buffer (cell density-58.0 $\times 10^{10}$ cells $\mathrm{mL}^{-1}$ ). This cell suspension $(200 \mu \mathrm{L})$ was mixed with $50 \mu \mathrm{L}$ $\left(200 \mu \mathrm{g} \mathrm{mL}^{-1}\right.$ ) of $4-\mathrm{NQO}$ and $750 \mu \mathrm{L}$ of sterile double distilled water. The mixture was incubated at $37^{\circ} \mathrm{C}$ for different time interval (15-60 min). After incubation, mutagen was inactivated by addition of $100 \mu \mathrm{L}$ of $10 \%$ $(w / v)$ sodium thiocynate followed by further incubation for $5 \mathrm{~min}$. The mutagenized cells were harvested by centrifugation at $10,000 \times \mathrm{g}$ for $5 \mathrm{~min}$, washed with phosphate buffer (100 mM, pH 7.2) and re-suspended in sterile distilled water.

Preliminary screening of lipase-overproducing mutants was done on tributyrin agar medium $(\mathrm{pH} 9.0)$ prepared by supplementing the nutrient agar with $1 \%$ $(\mathrm{v} / \mathrm{v})$ tributyrin. The treated cell suspension was diluted and spread on a series of pre-sterilized plates of above mentioned medium and incubated at $37^{\circ} \mathrm{C}$ for $24-48 \mathrm{~h}$. The bacterial colonies forming the largest clear zone were isolated at randomly from different plates.
Screening of a potent over-producing mutant strain: The selected mutants were grown in the basal fermentation medium comprising $\left(\mathrm{g} \mathrm{L}^{-1}\right)$ : $\left(\mathrm{NH}_{4}\right)_{2} \mathrm{SO}_{4}$, $1.0 ; \mathrm{KH}_{2} \mathrm{PO}_{4}, 0.6 ; \mathrm{MgSO}_{4}, 0.2$; yeast extract, 0.1 ; olive oil, 20; gum arabic, 5.0 and $\mathrm{pH} 9.0$ to determine their potencies for alkaline lipase production in shake flask. Fermentation experiments were performed at $37^{\circ} \mathrm{C}$ and $120 \mathrm{rpm}$ in $250 \mathrm{~mL}$ flasks containing $50 \mathrm{~mL}$ medium, inoculated with $1 \%(\mathrm{v} / \mathrm{v})$ of the seed culture. At the end of fermentation process, the flasks were taken and harvested to measure the lipase activity in the fermented broth.

Analytical methods: Extracellular lipase activity was measured spectrophotometrically by following the method of Winkler and Stuckman (1979) with slight modifications. The substrate solution containing $10 \mathrm{~mL}$ of isopropanol with $30 \mathrm{mg}$ of p-nitrophenyl palmitate was mixed with $90 \mathrm{~mL}$ of Tris- $\mathrm{HCl}$ buffer $(50 \mathrm{mM}, \mathrm{pH}$ 9.0), containing $0.4 \%$ Triton-X-100 and $100 \mathrm{mg}$ of gum arabic. Freshly prepared substrate solution $(2.4 \mathrm{~mL})$ was incubated at $37^{\circ} \mathrm{C}$ with $25 \mu \mathrm{L}$ of s uitably diluted cell-free supernatant for $15 \mathrm{~min}$. After incubation absorbance was measured at $410 \mathrm{~nm}$ by using a spectrophotometer (UV-1601, Shimadzu) against a control with heat inactivated enzyme. One unit of enzyme is defined as the amount of enzyme liberating 1 $\mu \mathrm{g}$ of $\mathrm{p}$-nitrophenol $\mathrm{mL}^{-1} \mathrm{~min}^{-1}$ under the assay conditions.

Development of bioprocess for lipase production by mutant strain M-05: The protocol adopted for optimization of process parameters aimed to evaluate the effect of an individual parameter at a time and to incorporate it at the standard level before optimizing the next parameter.

Selection of physical parameters: The effect of incubation period on growth and alkaline lipase production was monitored in the basal medium used previously for screening. Samples $(3 \mathrm{~mL})$ were harvested at every $4 \mathrm{~h}$ intervals for both bacterial growth and lipase production. Absorbance at $610 \mathrm{~nm}$ was measured for the determination of biomass. The influence of initial $\mathrm{pH}$ and incubation temperature on alkaline lipase production was studied by adjusting the $\mathrm{pH}$ of the basal medium at different levels (8.0-10.0) then incubated at temperatures $30-45^{\circ} \mathrm{C}$ (at difference of $\left.5^{\circ} \mathrm{C}\right)$. The effect of inoculum sizes $(0.25-2.5 \%$, v/v) were also investigated on lipase production.

Selection of nutritional parameters: The effect of various medium supplements such as oils $(2.0 \% \mathrm{v} / \mathrm{v}$; 
castor, neem, mustard, linseed and groundnut oil), carbon source additives $(0.5 \% \mathrm{w} / \mathrm{v}$; fructose, glucose, lactose, mannitol, soluble starch, sorbitol and sucrose), organic nitrogen sources $(0.1 \% \mathrm{w} / \mathrm{v}$; corn steep liquor, gelatin, malt extract, peptone, tryptone and yeast extract), inorganic nitrogen sources $(0.1 \% \mathrm{w} / \mathrm{v}$; sodium nitrate, ammonium nitrate, ammonium chloride, potassium nitrate, di-ammonium hydrogen orthophosphate and ammonium di-hydrogen orthophosphate), metal salts $\left(0.02 \%\right.$, w/v $\mathrm{FeSO}_{4}, \mathrm{CaCl}_{2}$, $\mathrm{MnCl}_{2}, \quad \mathrm{ZnCl}_{2}, \quad \mathrm{CuSO}_{4}, \mathrm{HgCl}_{2}$ and $\left.\mathrm{NiCl}_{2}\right)$ and surfactants $(0.1 \%$, Tween-80, Triton-X-100, SDS, Tween-40 and Tween-20) on enzyme production was studied by incorporating the constituent individually in the production medium.

Statistical analysis: All experiments were carried out in triplicates and the results are presented as the mean of three independent observations. Standard deviation for each experimental result was calculated using Microsoft Excel.

\section{RESULTS}

Mutagenesis and screening of mutants: The observations of strain improvement through chemical mutagenesis suggest that lethality of viable cells increased with the increase in exposure time with mutagen and only $0.12 \%$ viable cells were recorded after $60 \mathrm{~min}$ of incubation (data not shown). Several mutant strains (twenty four) showing zone of lipolysis on the tributyrin plates were selected at randomly from the plates of different exposure time interval and tested for lipase production in shake flask. Mutant strains such as M-01, M-05, M-09, M-12 and M-21, showed remarkable over production of alkaline lipase (data not shown). Among the various mutants, the maximum lipase production was achieved by the mutant M-05 (160.9 $\mathrm{U} \mathrm{mL}^{-1}$ ) which was approximately 3.6-fold higher as compared to the wild-type strain. Hence, mutant strain M-05 was selected for further study.

Optimization of cultural parameters for lipase production:

Growth kinetics and enzyme production: A timecourse study was conducted in order to determine the growth and lipase production level by the mutant strain with regard to incubation period (Fig. 1). The logarithmic phase commenced at $8 \mathrm{~h}$ and continued for another $20 \mathrm{~h}$ and maximum growth was achieved after $28 \mathrm{~h}$ of incubation at $37^{\circ} \mathrm{C}$. With regard to lipase production, it commenced in early logarithmic phase (after $12 \mathrm{~h}$ ) and increased until maximum production was achieved (283.4 $\left.\mathrm{U} \mathrm{mL}^{-1}\right)$ after $28 \mathrm{~h}$ of incubation.
Further increase in incubation period did not lead to an increase in lipase production, rather a slow decrease in lipase yield was observed.

Effect of inoculum size on alkaline lipase production: The inoculum concentration was studied to obtain optimum size of inoculum and results indicated that lipase production increased with an increase in inoculum size (Fig. 2). Maximum lipase production $\left(348.6 \mathrm{U} \mathrm{mL}^{-1}\right)$ was obtained at $0.5 \%(\mathrm{v} / \mathrm{v})$ inoculum size, however, further increase in inoculum size resulted in sharp decrease in lipase production, especially when $2.5 \%$ (v/v) inoculum size was used.

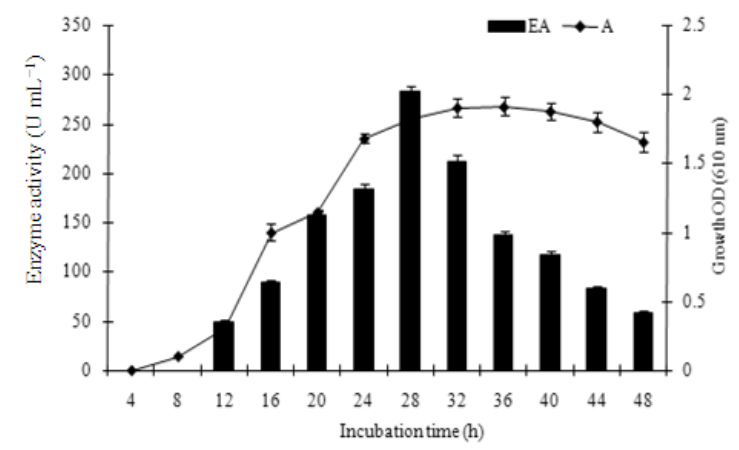

Fig. 1: Growth kinetics along with the alkaline lipase production. EA- Enzyme Activity, AAbsorbance. Inoculated flasks were incubated at $37^{\circ} \mathrm{C}$ at $120 \mathrm{rpm}$ for $48 \mathrm{~h}$. Samples were harvested at every $4 \mathrm{~h}$ and assayed for lipase activity and biomass determination (Absorbance at $610 \mathrm{~nm}$ ). Bars presented are mean values of \pm standard deviation of triplicates of three independent experiments

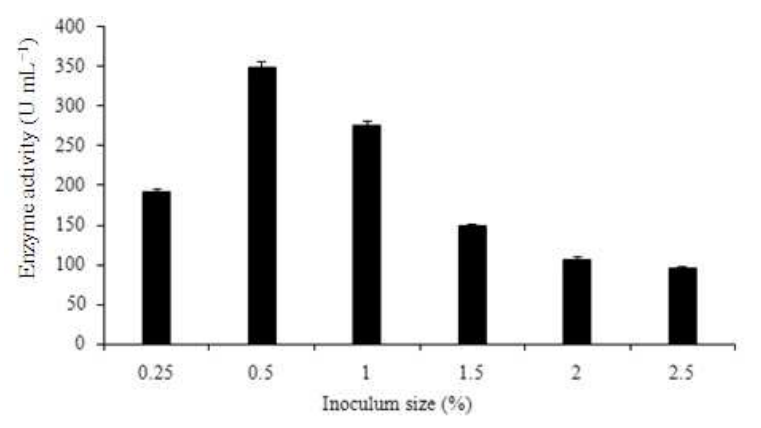

Fig. 2: Effect of inoculum size on alkaline lipase production. The inoculated flasks were incubated at $37^{\circ} \mathrm{C}$ for $28 \mathrm{~h}$ at $120 \mathrm{rpm}$. The flasks having $1 \%(\mathrm{v} / \mathrm{v})$ inoculum was taken as control. Bars presented are mean values of \pm standard deviation of triplicates of three independent experiments 


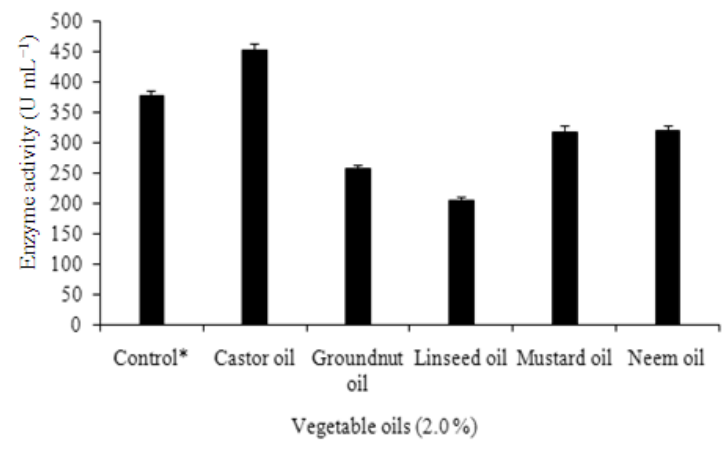

Fig. 3: Influence of various vegetable oils on alkaline lipase production. The control flasks contained olive oil $(2.0 \% \mathrm{v} / \mathrm{v})$. Test flasks contained different oils in the medium replacing olive oil at a level of $2.0 \%(\mathrm{v} / \mathrm{v})$. Inoculated flasks were incubated at $35^{\circ} \mathrm{C}$ for $28 \mathrm{~h}$. Bars presented are mean values of \pm standard deviation of triplicates of three independent experiments

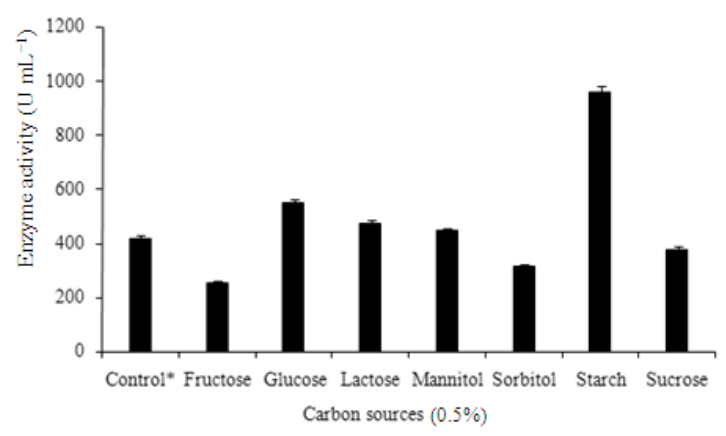

Fig. 4: Influence of various additional carbon sources on alkaline lipase production. The control contained castor oil $(2.0 \% \mathrm{v} / \mathrm{v})$ without any additional carbon source. Test flasks contained different sugar in the medium with castor oil. Inoculated flasks were incubated at $35^{\circ} \mathrm{C}$ for 28 h. Bars presented are mean values of \pm standard deviation of triplicates of three independent experiments

Table 1: Effect of temperature and $\mathrm{pH}$ on alkaline lipase production. The inoculated flasks were incubated at different temperatures for $28 \mathrm{~h}$ under shaking condition $(120 \mathrm{rpm})$. The \pm values in the columns showed the standard deviation of three independent trials

Enzyme activity $\left(\mathrm{U} \mathrm{mL}^{-1}\right)$

Temperature $\left({ }^{\circ} \mathrm{C}\right)$

\begin{tabular}{lllll}
$\mathrm{pH}$ & \multicolumn{1}{c}{30} & 35 & 40 & 45 \\
\hline 8.0 & $150.5 \pm 2.9$ & $170.4 \pm 5.3$ & $165.4 \pm 5.8$ & $108.6 \pm 0.8$ \\
8.5 & $161.2 \pm 3.8$ & $254.4 \pm 8.1$ & $184.9 \pm 4.8$ & $134 \pm 3.9$ \\
9.0 & $277.4 \pm 8.0$ & $381.8 \pm 10.7$ & $219.4 \pm 6.1$ & $154.4 \pm 4.5$ \\
9.5 & $171.9 \pm 4.6$ & $211.3 \pm 8.7$ & $165.3 \pm 5.6$ & $125.8 \pm 4.4$ \\
10.0 & $99.3 \pm 2.4$ & $154.9 \pm 3.9$ & $124.1 \pm 3.8$ & $88.6 \pm 2.9$ \\
\hline
\end{tabular}

Effect of $\mathrm{pH}$ and temperature on alkaline lipase production: It is evident from Table 1 that substantial quantity of lipase was produced by mutant strain at all the $\mathrm{pH}$ and temperature levels tested except $\mathrm{pH} 10$ and temperature $45^{\circ} \mathrm{C}$. The maximum lipase was produced at $\mathrm{pH} 9.0$ and temperature $35^{\circ} \mathrm{C}$ with the enzyme activity of $381.8 \mathrm{U} \mathrm{mL}^{-1}$.

Effect of vegetable oils on lipase production: Different lipid sources as substrate had different effects on alkaline lipase production (Fig. 3). Of all the lipidic sources tested, the highest lipolytic activity of $453.0 \mathrm{U}$ $\mathrm{mL}^{-1}$ was obtained with castor oil followed by olive oil (377.8 $\left.\mathrm{U} \mathrm{mL}^{-1}\right)$ and mustard oil $\left(318.5 \mathrm{U} \mathrm{mL}^{-1}\right)$. However, groundnut oil and neem oil also supported lipase production. Contrastingly, linseed oil reported very low lipase production $\left(204.9 \mathrm{U} \mathrm{mL}^{-1}\right)$ which could be due to hampered growth of the strains as evident by the absence of any visible turbidity in the medium.

Effect of additional carbon sources on alkaline lipase production: Addition of different additional carbon sources had both positive and negative effect on alkaline lipase production (Fig. 4). Maximum lipase production was obtained with starch $\left(960.8 \mathrm{U} \mathrm{mL}^{-1}\right)$ followed by glucose $\left(550.9 \mathrm{U} \mathrm{mL}^{-1}\right)$ and lactose $(476.1$ $\mathrm{U} \mathrm{mL}^{-1}$ ), whereas, mannitol (448.1 $\mathrm{U} \mathrm{mL}^{-1}$ ), sucrose (380.4 $\mathrm{U} \mathrm{mL}^{-1}$ ) and fructose (253.9 $\mathrm{U} \mathrm{mL}^{-1}$ ) had negative effect on lipase production.

Owing to the effect of starch we optimized several combinations of castor oil and starch in the production medium (Table 2). Marked increase in lipase production (1098.8 $\mathrm{U} \mathrm{mL} \mathrm{mL}^{-1}$ ) was observed with combination 1 (castor oil $0.2 \% \mathrm{v} / \mathrm{v}+$ starch $2.0 \% \mathrm{w} / \mathrm{v}$ ), whereas, other combinations were ineffectual as compared to control.

Effect of different organic nitrogen sources on lipase production: A range of organic nitrogen sources were tested to evaluate their capacity to support lipase production.

Table 2: Effect of different combinations of castor oil and starch on lipase production. The inoculated flasks were incubated at $35^{\circ} \mathrm{C}$ for $28 \mathrm{~h}$ under shaking condition $(120 \mathrm{rpm})$. The \pm values in the columns showed the standard deviation of three independent trials

\begin{tabular}{llc}
\hline Combinations & $\begin{array}{l}\text { Castor oil + starch } \\
(\%)\end{array}$ & $\begin{array}{c}\text { Enzyme activity } \\
\left(\mathrm{U} \mathrm{mL}^{-1}\right)\end{array}$ \\
\hline Control & $2.0+0.0$ & $964.1 \pm 21$ \\
1 & $0.2+2.0$ & $1098.8 \pm 20.6$ \\
2 & $0.5+1.5$ & $917.8 \pm 18.3$ \\
3 & $1.0+1.0$ & $449.0 \pm 8.9$ \\
4 & $1.5+0.5$ & $531.9 \pm 15.4$ \\
5 & $2.0+0.5$ & $657.6 \pm 18.0$ \\
6 & $0.0+2.0$ & $154.2 \pm 3.0$ \\
\hline
\end{tabular}




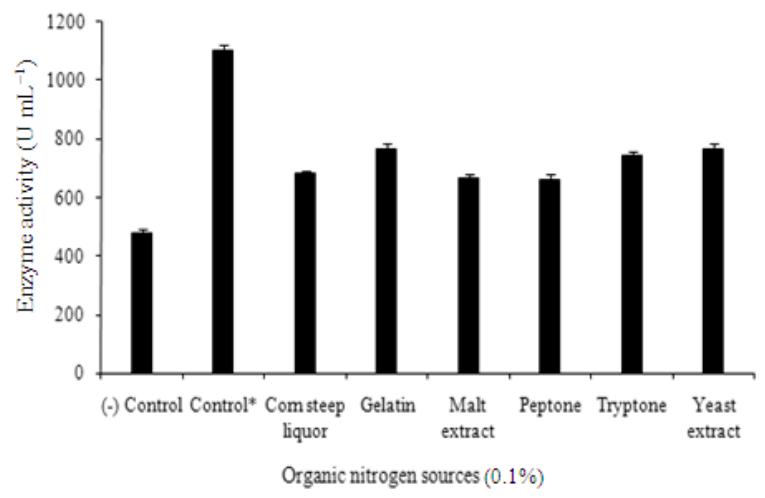

Fig. 5: Influence of various organic nitrogen sources on alkaline lipase production. Negative control was without yeast extract. Positive control contained yeast extract $(0.01 \% \mathrm{w} / \mathrm{v})$. Test flasks contained different nitrogen source $(0.1 \% \mathrm{w} / \mathrm{v})$ in the medium replacing yeast extract. Inoculated flasks were incubated at $35^{\circ} \mathrm{C}$ for 28 h. Bars presented are mean values of \pm standard deviation of triplicates of three independent experiments

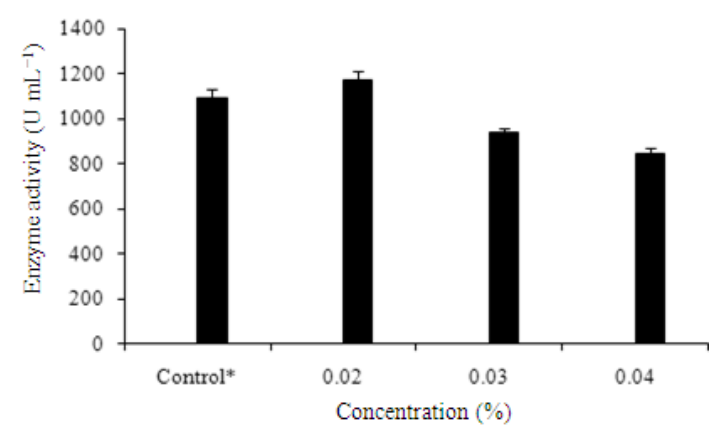

Fig. 6: Effect of different concentration of yeast extract on alkaline lipase production. The control flasks contained yeast extract $(0.01 \%$ w/v). Test flasks contained different concentration of yeast extract $(0.02-0.04 \% \mathrm{w} / \mathrm{v})$ in the medium. The inoculated flasks were incubated at $35^{\circ} \mathrm{C}$ for $28 \mathrm{~h}$ under shaking condition (120 rpm). Bars presented are mean values of \pm standard deviation of triplicates of three independent experiments

Figure 5 showed that mutant strain produced significant lipase with all the organic nitrogen sources, however, maximum lipase production $\left(1100.6 \mathrm{U} \mathrm{mL}^{-1}\right)$ was attained in control (yeast extract- $0.01 \% \mathrm{w} / \mathrm{v}$ ), whereas inhibition in lipase production was observed in the medium devoid of yeast extract.

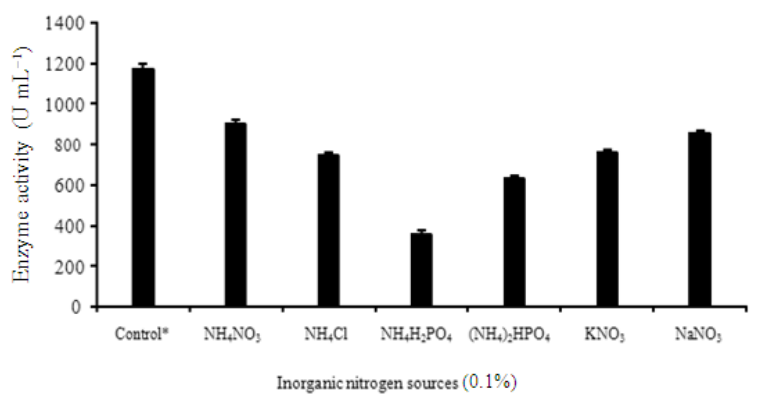

Fig. 7: Influence of various inorganic nitrogen sources on alkaline lipase production. The control flasks contained ammonium sulphate $(0.1 \%$ w/v). Test flasks contained different inorganic nitrogen sources $(0.1 \% \mathrm{w} / \mathrm{v})$ in the medium substituting ammonium sulphate. Inoculated flasks were incubated at $35^{\circ} \mathrm{C}$ for $28 \mathrm{~h}$. Bars presented are mean values of \pm standard deviation of triplicates of three independent experiments

Owing to effect of yeast extract different concentration $(0.01-0.04 \%, \mathrm{w} / \mathrm{v})$ were studied on lipase production. It was observed that $0.02 \%(\mathrm{w} / \mathrm{v})$ exhibited marginal increase in lipase yield i.e., $1175.9 \mathrm{U} \mathrm{mL}^{-1}$ (Fig. 6). Further increase in concentration of yeast extract, resulted in gradual decrease in lipase production.

Effect of different inorganic nitrogen sources on lipase production: It is observed from Fig. 7 that all the inorganic nitrogen sources supplemented in the production medium tend to decrease the lipase production except the medium containing ammonium sulphate i.e., control $\left(1170.6 \mathrm{U} \mathrm{mL}^{-1}\right)$. In case of ammonium di-hydrogen orthophosphate minimum lipase yield was observed $\left(356.9 \mathrm{U} \mathrm{mL}^{-1}\right)$.

When different concentrations of ammonium sulphate were added to the medium it didn't exhibit significant increase in lipase production and maximum lipase yield $\left(1167.4 \mathrm{U} \mathrm{mL}^{-1}\right)$ was attained in control $(0.1 \%$, w/v) (Fig. 8). Whereas, lipase production was completely repressed at concentration $0.4 \%$.

Effect of metal salts on lipase production: Figure 9 depicts the influence of various metal salts on lipase synthesis. Maximum enzyme production (1187.4 U $\mathrm{mL}^{-1}$ ) was observed in control containing $\mathrm{MgSO}_{4}$ followed by $\mathrm{FeSO}_{4}\left(999.9 \mathrm{U} \mathrm{mL}^{-1}\right)$, however, rest of the metals $\left(\mathrm{CuSO}_{4}, \mathrm{HgCl}_{2}\right.$ and $\left.\mathrm{NiCl}_{2}\right)$ did not stimulate the lipase production. Owing to effect of $\mathrm{MgSO}_{4}$, we varied its concentration in the range of $0.02-$ $0.08 \%$ into the production medium. The maximum yield 
(1254.9 $\mathrm{U} \mathrm{mL}^{-1}$ ), with trivial increase, was obtained with $0.04 \%(\mathrm{w} / \mathrm{v})$ concentration (Fig. 10). Further increase in $\mathrm{MgSO}_{4}$ concentration resulted in gradual decrease in lipase production with minimum at concentration $0.08 \%$ $(\mathrm{w} / \mathrm{v})$.

Effect of surfactants on alkaline lipase production: Influence of surfactants on alkaline lipase production is presented in Fig. 11. Results revealed that the lipase production was profoundly affected by types of surfactants used.

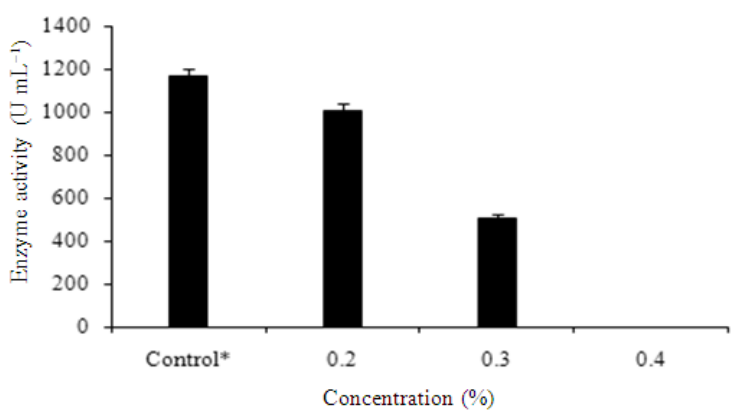

Fig. 8: Effect of different concentration of ammonium sulphate on alkaline lipase production. The control flasks contained ammonium sulphate $(0.1 \% \mathrm{w} / \mathrm{v})$. Test flasks contained different concentration of ammonium sulphate $(0.2-0.4 \%$ $\mathrm{w} / \mathrm{v})$ in the medium. Inoculated flasks were incubated at $35^{\circ} \mathrm{C}$ for $28 \mathrm{~h}$. Bars presented are mean values of \pm standard deviation of triplicates of three independent experiments

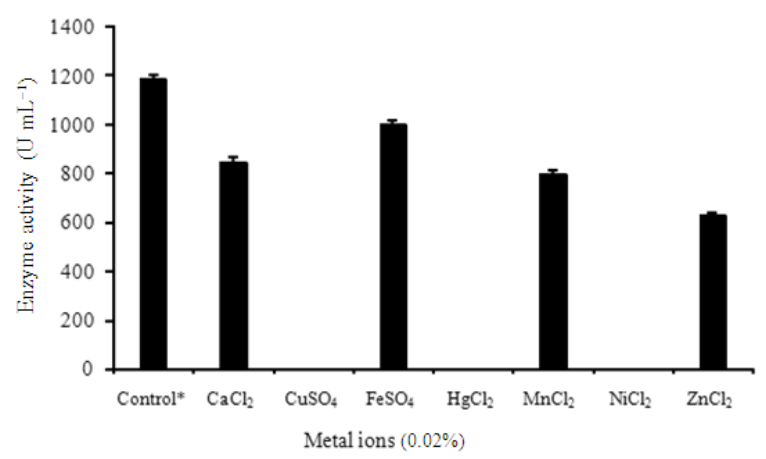

Fig. 9: Effect of various metal salts on alkaline lipase production. The control flasks contained $\mathrm{MgSO}_{4}$ $(0.02 \% \mathrm{w} / \mathrm{v})$. Test flasks contained different metal ions in the medium replacing $\mathrm{MgSO}_{4}$. Inoculated flasks were incubated at $35^{\circ} \mathrm{C}$ for 28 h. Bars presented are mean values of \pm standard deviation of triplicates of three independent experiments
Mutant strain of $P$. aeruginosa MTCC 10,055 showed maximum lipase production (2368.7 $\mathrm{U} \mathrm{mL}^{-1}$ ) with Triton-X-100, whereas, Tween-80, SDS and Tween-40 did not have any significant effect on lipase production as compared to control. Supplementation of Tween-40 in the production medium tend to decrease the lipase yield (454.4 U $\left.\mathrm{mL}^{-1}\right)$.

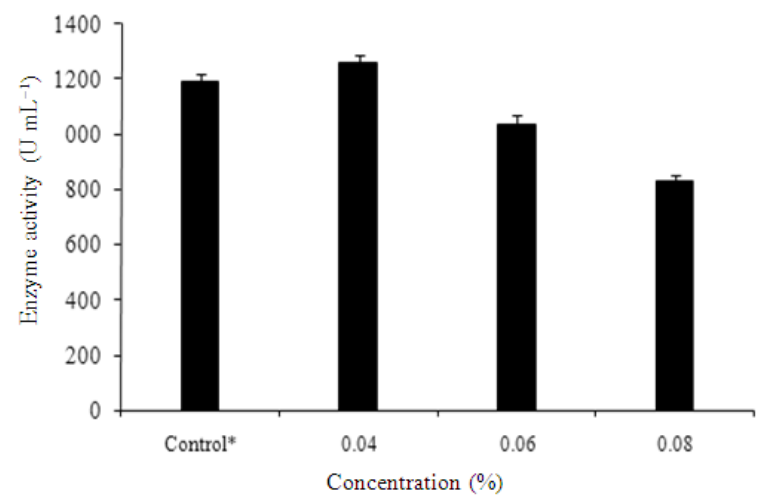

Fig. 10: Effect of different concentration of $\mathrm{MgSO}_{4}$ on alkaline lipase production. The control flasks contained $\mathrm{MgSO}_{4}(0.02 \%)$. Test flasks contained different concentration of $\mathrm{MgSO}_{4}$ (0.04-0.08\%) in the medium. Inoculated flasks were incubated at $35^{\circ} \mathrm{C}$ for $28 \mathrm{~h}$. Bars presented are mean values of \pm standard deviation of triplicates of three independent experiments

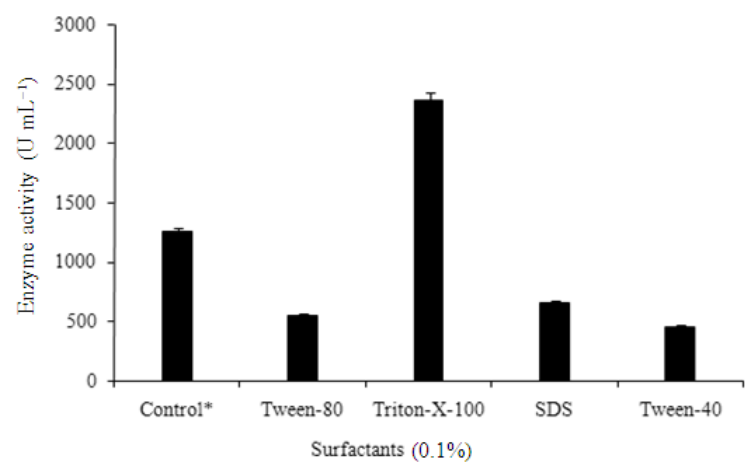

Fig. 11: Influence of various surfactants on alkaline lipase production. The control flasks were without any surfactant. Test flasks contained different surfactant $(0.1 \%)$ in the medium. Inoculated flasks were incubated at $35^{\circ} \mathrm{C}$ for $28 \mathrm{~h}$. Bars presented are mean values of \pm standard deviation of triplicates of three independent experiments 
Am. J. Applied Sci., 9 (2): 158-167, 2012

\section{DISCUSSION}

The mutation and screening of industrially useful microorganisms are important for the successful development of the various strains required in the fermentation industry. Zhao et al. (2010) reported 2.3fold increase in the lipase from a mutant strain of Serratia marcescens as compared to wild type strain after exposure to Ultra Violet (UV). Gaoa et al. (2000), also reported 3.25-fold increase in lipase yield by mutant of Pseudomonas upon exposure to UV and Nmethyl-N'-nitro-N-nitrosogunidine (NTG).

Kinetic study of the growth and alkaline lipase production by the mutant strain demonstrated that optimum lipase production occurred after $28 \mathrm{~h}$, thereafter decreased on further incubation (Fig. 1). Rosenau and Jaeger (2000) also reported synthesis of extracellular lipase in the late logarithmic phase of growth and suggested that the two-component system lipQ/R, which directly controls lipA gene expression is subjected to a superior quorum sensing system. Similarly, Sekhon et al. (2006) reported a high level of lipase activity after $27 \mathrm{~h}$ incubation.

The nature of inoculum as well as its size may affect the microbial process and could play crucial role in enzyme production (Elibol et al., 1995). In a study of lipase production by Bacillus thermoleovorans ID-1, Lee et al. (1999) obtained optimum results when 1\% $(\mathrm{v} / \mathrm{v})$ inoculum was used to inoculate the fermentation medium. At a suitable inoculum size, the nutrient and oxygen levels support sufficient growth of bacteria and therefore, enhance the lipase production. Higher inoculum size may cause insufficiency of total dissolved oxygen and nutrient supply in the culture media resulting in poor product yield (Baharum et al., 2003). If the inoculum size is too small, insufficient biomass lead to reduced level of secreted lipase.

The present study revealed that the lipase production by the mutant strains requires alkaline $\mathrm{pH}$ 9.0, which is relatively high when compared to lipase production by Bacillus megaterium AKG-1 DSM 730 (Sekhon et al., 2006) and low when compared to Arthobacter sp. BGCC\# 490 (Sharma et al., 2009). Invariably, the lipase production by Serratia marcences prefers slightly acidic $\mathrm{pH}$ (6.5-7.0) (Gao et al., 2004).

Our results indicated that the optimum temperature for lipase productivity by the mutant strains was $35^{\circ} \mathrm{C}$. Many workers investigated the relation of temperature and lipase production. Gunasekaran et al. (2006) observed similar results where the optimum temperature for lipase produced by Citrobactor freundii was $35^{\circ} \mathrm{C}$. In addition, Baharum et al. (2003) investigated the production of lipase by Pseudomonas sp. strain S5 and recorded that the optimum temperature for lipase production was $37^{\circ} \mathrm{C}$.

The major factor for the expression of lipase activity has always been reported as the carbon source, since lipases are mostly inducible enzymes and sometimes constitutive, although their role in lipase synthesis and stimulation is poorly understood (Large et al., 1999). Among the various oils used in the present study, maximum lipase production was achieved with castor oil followed by olive oil and mustard oil. These findings are supported by the study of Kulkarni and Gadre (2002) and Sharon et al. (1998) who also reported the castor oil to be the most effective oil for lipase production by $P$. fluorescens $\mathrm{NS} 2 \mathrm{~W}$ and $P$. aeruginosa KKA-5, respectively. On the contrary to our results, neem oil and olive oil were found to good for lipase production by Fusarium globulosum (Gulati et al., 2005) and Bacillus sp. (Shah et al., 2007). Macris et al. (1996) suggested that the carbon chain moiety of the fatty acid present in the triglycerol can control the lipase synthesis.

For lipase production different lipid based carbon sources have been reported as inducer as well as carbon source (alone or in combination with carbohydrates) by several researchers. Therefore, the suitability of different carbon source additive for lipase production by mutant strain was investigated. Supplementation of production medium with starch tremendously boosted the lipase activity (about 129.3\%) as compared to control. Similar results were reported by Pogaku et al. (2010), while investigating the lipase production by Staphylococcus sp. Lp12. Rathi et al. (2001) also reported increase in lipase production from Burkholderia cepacia in the presence of oil and glucose as sugar additive.

Among the various nitrogen sources tested, a significant increase in growth and lipase production was observed with yeast extract. Likewise, maximum lipase production with $0.1 \%(\mathrm{w} / \mathrm{v})$ and $0.5 \%(\mathrm{w} / \mathrm{v})$ yeast extract have also been reported earlier by Bacillus strain A30-1 (Wang et al., 1995) and P. citrinum (Pimentel et al., 1994), respectively. According to Gupta et al. (2007) yeast extract apart from acting as a nitrogen source also supplies vitamins and trace metals, thereby affecting the growth of organism in turn, increase in lipase production.

Among the inorganic nitrogen sources studied, the ammonium sulphate was found to be most suitable for lipase production, whereas ammonium di-hydrogen orthophosphate inhibited the lipase production and others had insignificant effect. Lima et al. (2003) also reported that ammonium salt was necessary for growth of $P$. aurantiogriseum. In contrast, Pogaku et al. (2010) 
found that potassium nitrate was better than ammonium sulphate for increased lipase production by Staphylococcus sp. LP12.

As metal ions are known to influence lipase synthesis, activity and secretion mechanism (Lee et al., 2007), various metal salts in the medium were evaluated for their effect on alkaline lipase production. Maximum enzyme production was observed in control containing $\mathrm{MgSO}_{4}$ followed by $\mathrm{FeSO}_{4}$. Shah et al. (2007) have also reported similar results with Bacillus sp. (Pa2) for increased lipase production when $\mathrm{Mg}^{+2}$ $(0.25 \%, \mathrm{w} / \mathrm{v})$ was incorporated into the production medium. On the other hand, influence of $\mathrm{Ca}^{+2}$ in addition to $\mathrm{Mg}^{+2}$ was found to enhance lipase production by $P$. aeruginosa (Kulkarni and Garde, 2002).

Among the various surfactants tested, a significant increase in lipase production was observed with Triton$\mathrm{X}-100$. The lipase production rapidly decreased when Tween-80 and SDS were used, whereas, Tween-40 did not have any significant effect. According to $\mathrm{Wu}$ and Tsai (2004), higher levels of lipase production were observed when the substrate formed an emulsion, thereby presenting an interfacial area to the enzyme. This has resemblance with the earlier $P$. pseudoalkaligens F-111 lipase, where addition of Triton-X-100 increased the alkaline lipase production by 50-fold (Lin et al., 1995). An elaborated study was done by Lin et al. (1995) on effect of Triton-X-100 on lipase production. Triton-X-100 may directly act as a positive activator of lipase gene or may induce the expression of lipase gene by removing the repressor molecules. They also inferred that Triton-X-100 mechanistically promotes both uptake and exit of compounds from the cell through modification of plasma membrane permeability. Contrastingly, the studies on lipase production by Staphylococcus sp. indicated the positive influence of Tween-80 (Pogaku et al., 2010). However, surfactants do not always increase lipase production (Deive et al. 2003) and their effect varied with microorganism, type of surfactant and its concentration (Dominguez et al., 2003).

\section{CONCLUSION}

Improvement of microbial strains for the over production of industrial products has been the hallmark of all commercial fermentation processes. Effect of supplementation of castor oil and starch, in combination and Triton-X-100 were interesting findings where about 250 and $90 \%$ increase in lipase production was observed, respectively. In the present study, strain improvement goes hand-in-hand with medium and process improvement and the high titers are the results of both being employed synergistically. We have successfully developed a promising mutant strain, by employing a simpler technique of chemical mutagenesis, which can be exploited at bioreactor level for industrial production of alkaline lipase, a biotechnologically important hydrolytic enzyme.

\section{ACKNOWLEDGEMENTS}

Financial assistance to the researchers (Deepali Bisht) by University Grants Commission, New Delhi, in the form of Major Research Project is thankfully acknowledged. The assistance provided by the Government of Uttar Pradesh to the Department of Microbiology, Dr. Ram Manohar Lohia Avadh University, Faizabad under the scheme of Center of Excellence is duly acknowledged.

\section{REFERENCES}

Baharum, S.N., A.B.S. Razak, M.C. Basri, M.B.A. Rahman and R.N.Z.R.A. Rahman, 2003. Organic solvent tolerant lipase by Pseudomonas sp. strain S5: stability of enzyme in organic solvent and physical factors affecting its production. Ann. Microbiol., 53: 75-83.

Bapiraju, K.V.V.S.N., P. Sujatha, P. Ellaiah and T. Ramana, 2004. Mutation induced enhanced biosynthesis of lipase. Afr. J. Biotechnol., 3: 618-621.

Deive, F.J., M. Costas and M.A. Longo, 2003. Production of a thermostable extracellular lipase by Kluyveromyces marxianus. Biotechnol. Lett., 25: 1403-1406. DOI: 10.1023/A:1025049825720

Dominguez, A., M. Costas, M.A. Longo and A. Sanroman, 2003. A novel application of solid state culture: Production of lipases by Yarrowia lipolytica. Biotechnol. Lett., 25: 1225-1229. DOI: 10.1023/A:1025068205961

Elibol, M., K. Ulgen, K. Kamarulzaman and F. Mavituna, 1995. Effect of inoculum type on actinorhodin production by Streptomyces coelicolor. Biotechnol. Lett., 17: 579-582. DOI: 10.1007/BF00129381

Gao, L., J.H. Xu, X.J. Li and Z.Z. Liu, 2004. Optimization of Serratia marcescens lipase production for enantioselective hydrolysis of 3phenyl glycidic acid ester. J. Ind. Microbiol. Biotechnol., 31: 525-530. DOI: 10.1007/s10295004-0182-1 
Gaoa, X.G., S.G. Cao and K.C. Zhang, 2000. Production, properties and application to nonaqueous enzymatic catalysis of lipase from newly isolated Pseudomonas strain. Enz. Microb. Technol., 27: 74-82. DOI: 10.1016/S01410229(00)00191-5

Ghaly, A.E., D. Dave, M.S. Brooks and S. Budge, 2010. Production of biodiesel by enzymatic transesterification: Review. Am. J. Biochem. Biotechnol. 6: 54-76. DOI: 10.3844/ajbbsp.2010.54.76

Gulati, R., J. Isar, V. Kumar, A.K. Prasad and V.S. Parmar et al., 2005. Production of a novel alkaline lipase by Fusarium globulosum using neem oil and its applications. Pure Applied Chem., 77: 251-262. DOI: $10.1351 /$ pac200577010251

Gunasekaran, V., S.M. Kotay and D. Das, 2006. Alkaline lipase production by Citrobacter freundii IIT-BT L139. Ind. J. Exp. Biol., 44: 485-491.

Gupta, N., V. Shai and R. Gupta, 2007. Alkaline lipase from a novel strain Burkholderia multivorans: Statistical medium optimization and production in a bioreactor. Process Biochem., 42: 518-526. DOI: 10.1016/j.procbio.2006.10.006

Gupta, R., P. Rathi and S. Bradoo, 2003. Lipase mediated upgradation of dietary fats and oils. Crit. Rev. Food Sci. Nutr., 43: 635-644. DOI: 10.1080/10408690390251147

Houde, A., A. Kademi and D. Leblanc, 2004. Lipases and their industrial applications: An overview. Applied Biochem. Biotech., 118: 155-170. DOI: 10.1385/ABAB:118:1-3:155

Jaeger K.E. and M.T. Reetz, 1998. Microbial lipases form versatile tools for biotechnology. Trends Biotechnol., 16: 396-403. DOI: 10.1016/S01677799(98)01195-0

Jaeger K.E. and T. Eggert, 2002. Lipases for biotechnology. Curr. Opin. Biotechnol., 13: 390397. DOI: 10.1016/S0958-1669(02)00341-5

Kulkarni, N. and R.V. Garde, 2002. Production and properties of an alkaline thermophilic lipase from Pseudomonas fluorescens NS2W. J. Ind. Food. Microbiol., 28: 344-348. DOI: $10.1038 / \mathrm{sj} / \mathrm{jim} / 7000254$

Large, K.P., N. Mirjalili, M. Osborne, L.M. Peacock and V. Zormpaidis et al., 1999. Lipase activity in Streptomycetes. Enz. Microb. Technol., 25: 569575. DOI: 10.1016/S0141-0229(99)00080-0

Lee, D., Y. Kok, K. Kim, B. Kim and H. Choi et al., 1999. Isolation and characterization of a thermophilic lipase from Bacillus thermoleovorans ID-1. FEMS Microbiol. Lett., 179: 393-400. DOI: 10.1016/S0378-1097(99)00440-1
Lee, G., J. Bae, M. Suh and H. Kim, 2007. Optimal culture conditions for production of a novel extracellular alkaline lipase form Yarrowia lipolytica NRRL Y-2178. J. Applied Biol. Chem., 50: 46-51.

Lima, V.M.G., N. Krieger, M.I.M. Sarquis, D.A. Mitchell and L.P. Ramos et al., 2003. Effect of nitrogen and carbon sources on lipase production by Penicillium aurantiogriseum. Food Technol. Biotechnol., 41: 105-110.

Lin, S.F., C.M. Chioul and Y.C. Tsaiz, 1995. Effect of Triton-X-100 on alkaline lipase production by pseudomonas pseudoatcatigenes F-111. Biotechnol. Lett., 17: 959-962. DOI: 10.1007/BF00127434

Macris, J.B., E. Kourentzi and D.G. Hatzinikiolaou, 1996. Studies on localization and regulation of lipase production by Aspergillus niger. Process Biochem., 31: 807-812. DOI: 10.1016/S00329592(96)00037-4

Parekh, S., V.A. Vinci and R.J. Strobel, 2000. Improvement of microbial strains and fermentation processes. Applied Microbiol. Biotechnol., 54: 287-301. DOI: 10.1007/s002530000403

Pimentel, M.C., N. Krieger, L.C. Coelho, J.O. Fontana and E.H. Melo et al., 1994. Lipase from a Brazilian strain of Penicillium citrinum. Applied Biochem. Biotechnol., 49: 59-74. DOI: 10.1007/BF02888848

Pogaku, P., A. Suresh, P. Srinivaslu and S.A. Reddy, 2010. Optimization of lipase production by Staphylococcus sp. Lp12. Afr. J. Biotechnol., 9: 882-886.

Punt, P.J., R.P. Oliver, M.A. Dingemanse, P.H. Pouwels and C.A.M.J.J. Van den Hondel, 1987. Transformation of Aspergillus based on the hygromycin B resistance marker from Escherichia coli. Gene, 56: 117-124. DOI: 10.1016/03781119(87)90164-8

Rathi, P., R.K. Saxena and R. Gupta, 2001. A novel alkaline lipase from Burkholderia cepacia for detergent formulation. Process Biochem. 37: 187192. DOI: 10.1016/S0032-9592(01)00200-X

Rosenau, F. and K.E. Jaeger, 2000. Bacterial lipases from Pseudomonas: Regulation of gene expression and mechanisms of secretion. Biochimie, 82: 10231032. DOI: 10.1016/S0300-9084(00)01182-2

Sekhon, A., N. Dahiya, R.P. Tewari and G.S. Hoondal, 2006. Production of extracellular lipase by Bacillus megaterium AKG-1 in submerged fermentation. Ind. J. Biotechnol., 5: 179-183.

Shah, K.R., P.M. Patel and S.A. Bhatt, 2007. Lipase production by Bacillus sp. under different physicochemical conditions. J. Cell Tissue Res., 7: 913-916. 
Sharma, A., D. Bardhan and R. Patel, 2009. Optimization of physical parameters for lipase production from Arthrobacter sp. BGCC\#490. Ind. J. Biochem. Biophys., 46: 178-183.

Sharon, C., S. Furugoh, T. Yamakido, H. Ogawa and Y. Kato, 1998. Purification and characterization of a lipase from Pseudomonas aeruginosa KKA-5 and its role in castor oil hydrolysis. J. Ind. Microbiol. 20: 304-307. DOI: 10.1038/sj.jim.2900528

Stanbury, P., A. Whitaker and S. Hall, 1995. Fermentation Economics. 2nd Edn., Pergamon Press, UK., pp: 331-341.

Wang, Y., K.C. Srivastava, G.J. Shen and H.Y. Wang, 1995. Thermostable alkaline lipase from a newly isolated thermophilic Bacillus strain A30-1 (ATCC 53841). J. Ferment. Bioeng., 5: 433-438. DOI: 10.1016/0922-338X(95)91257-6
Winkler, U.K. and M. Stuckmann, 1979. Glycogen, hyaluronate and some other polysaccharides greatly enhance the formation of exolipase by Serratia marcescens. J. Bacteriol., 138: 663-670.

Wu, H.S. and M.J. Tsai, 2004. Kinetics of tributyrin hydrolysis by lipase. Enz. Microb. Technol., 35: 488-493. DOI: 10.1016/j.enzmictec.2004.08.002

Zhao, L.L., X.X. Chen and J.H. Xu, 2010. Strain improvement of Serratia marcescens ECU1010 and medium cost reduction for economic production of lipase. World J. Microbiol. Biotechnol., 26 : 537-543. DOI: 10.1007/s11274009-0203-3 